\title{
New snow metrics for a warming world
}

\author{
Anne Nolin ${ }^{1}$, Eric Sproles ${ }^{2}$, David Rupp ${ }^{3}$, Ryan Crumley ${ }^{3}$, Ross Palomaki ${ }^{2}$, and Eugene \\ $\operatorname{Mar}^{3}$ \\ ${ }^{1}$ University of Nevada Reno \\ ${ }^{2}$ Montana State University Bozeman \\ ${ }^{3}$ Oregon State University
}

October 31,2020

\begin{abstract}
Snow is Earth's most climatically sensitive land cover type. Air temperature and moisture availability are first-order controls on snowfall. Maximum snowfall occurs at temperatures very near $0^{\circ} \mathrm{C}$, so even a slight increase in temperature will shift a snowy winter to one with midseason rainfall and melt events. Traditional snow metrics are not able to adequately capture the changing nature of snow cover. For example, April 1 snow water equivalent (SWE, the amount of water represented by the snowpack) is used as a streamflow predictor. Still, it cannot express the effects of midwinter melt events, now expected in warming snow climates. The multiple impacts of a changing snowpack require a suite of climate indicators derived from readily measured or modelled data that serve as proxies for relevant snow-related and climate-driven processes. Such indicators need to be simple enough to "tell the story" of snowpack changes over space and time, but not overly simplistic as to be conflated with other variables or, conversely, overly complicated in their interpretation. This paper describes a targeted set of spatially explicit, multi-temporal snow metrics for multiple sectors, stakeholders, and scientists. They include metrics based on satellite data from NASA's Moderate Resolution Imaging Spectroradiometer, meteorological observations and snow data from ground-based stations, and climate model output. We describe and provide examples for Snow Cover Frequency (SCF), Snow Disappearance Date (SDD), snowstorm temperature (ST), At-Risk Snow (ARS), and Frequency of a Warm Winter (FWW).
\end{abstract}

Anne W. Nolin ${ }^{1}$, Eric A. Sproles ${ }^{2}$, David Rupp ${ }^{3}$, Ryan L. Crumley ${ }^{4}$, Ross T. Palomaki² and Eugene Mar $^{5}$ ${ }^{1}$ Department of Geography, University of Nevada, Reno, NV 89557, USA

${ }^{2}$ Department of Earth Sciences, Montana State University, Bozeman, MT 59717, USA

${ }^{3}$ Oregon Climate Change Research Institute, College of Earth, Ocean, and Atmospheric Sciences, Oregon State University, Corvallis, OR, 97331 USA

${ }^{4}$ College of Earth, Ocean, and Atmospheric Sciences, Oregon State University, Corvallis, OR, 97331 USA

${ }^{5}$ (retired) College of Earth, Ocean, and Atmospheric Sciences, Oregon State University, Corvallis, OR, 97331 USA

Corresponding Author : Anne W. Nolin, Department of Geography, University of Nevada, Reno, MS 0154, Reno, NV 89557, USA. Email: anolin@unr.edu

Abstract (up to 300 words)

Snow is Earth's most climatically sensitive land cover type. Air temperature and moisture availability are first-order controls on snowfall. Maximum snowfall occurs at temperatures very near $0^{\circ} \mathrm{C}$, so even a slight increase in temperature will shift a snowy winter to one with midseason rainfall and melt events. Traditional snow metrics are not able to adequately capture the changing nature of snow cover. For example, April 1 snow 
water equivalent (SWE, the amount of water represented by the snowpack) is used as a streamflow predictor. Still, it cannot express the effects of midwinter melt events, now expected in warming snow climates.

The multiple impacts of a changing snowpack require a suite of climate indicators derived from readily measured or modeled data that serve as proxies for relevant snow-related and climate-driven processes. Such indicators need to be simple enough to "tell the story" of snowpack changes over space and time, but not overly simplistic as to be conflated with other variables or, conversely, overly complicated in their interpretation.

This paper describes a targeted set of spatially explicit, multi-temporal snow metrics for multiple sectors, stakeholders, and scientists. They include metrics based on satellite data from NASA's Moderate Resolution Imaging Spectroradiometer, meteorological observations and snow data from ground-based stations, and climate model output. We describe and provide examples for Snow Cover Frequency (SCF), Snow Disappearance Date (SDD), snowstorm temperature (ST), At-Risk Snow (ARS), and Frequency of a Warm Winter (FWW).

Keywords: snow cover, climate change, remote sensing, SNOTEL, climate model, SnowCloudMetrics

\section{INTRODUCTION}

Snow is Earth's most climatically sensitive land cover type and is continuing to decline as temperatures warm and precipitation patterns shift (IPCC et al. , 2019). Air temperature and moisture availability are first-order controls on snowfall. Maximum snowfall occurs at temperatures very near $0^{\circ} \mathrm{C}$, so even a slight increase in temperature will shift a snowy winter to one with midseason rainfall and melt events (Jennings et al. , 2018). Snow cover variability affects multiple sectors, from water, energy, and forest management to transportation planning to outdoor recreation and tourism (Hagenstadet al. , 2018). Historically, snow monitoring has focused on ground-based measurements, with satellite remote sensing adding more capacity in the past several decades. While ground-based monitoring networks remain valuable, they do not have the spatial coverage, representative geospatial characterization, trend analysis, and predictive capabilities needed by researchers and water managers today (Milly et al. , 2008). Snow cover products derived from remote sensing require technical expertise and computing resources to produce and interpret, thereby limiting their broader usefulness. Here, we present a suite of snow metrics that may serve as key climate indicators to support the goals and needs of snow hydrologists, water managers, climate researchers, and various stakeholder groups.

The objectives of this research were to:

1. Produce new snow metrics for assessing past and future changes in snow cover and snowpacks;

2. Demonstrate how these snow-related climate indicators can be used to identify regions that may be vulnerable to future reductions in snow cover and warmer winters;

3. Provide web-based visualization tools to communicate these snow metrics.

This suite of snow-related climate indicators is created to address sector concerns and stakeholder questions such as: Where and how have the extent/duration/timing of snow cover changed in the past, and how might it change in the future? How might snowpack storage change over the next several decades in a particular watershed? Are winter storm temperatures different from aggregated temperature data, and have winter storm temperatures in the western US increased in recent years? What has been the climatological frequency of warm winters for vulnerable economic sectors such as ski areas? How might the frequency of warm winters change in mid-century and late-century?

The specific snow metrics include Snow Cover Frequency (SCF), Snow Disappearance Date (SDD), snowstorm temperature (ST), At-Risk Snow (ARS), and Frequency of a Warm Winter (FWW). This suite of metrics aims to provide information to a wide range of researchers and stakeholders, including hydrologists, climatologists, water and land managers, snow sports enthusiasts, climate adaptation planners, and others for whom snow plays a role in decision making. 


\subsection{Previously developed snow metrics and their limitations}

\subsubsection{April 1 Snow Water Equivalent}

The National Resources Conservation Service (NRCS) measures snow water equivalent along snow courses (survey transects) monthly and at automated SNOw TELemetry (SNOTEL) stations daily across the western United States. Snow water equivalent (SWE) is the amount of water represented by the snowpack (Serreze et al. , 1999). These NRCS sites were designed to serve as indices for seasonal streamflow forecasts based on regression-based relationships (Garen, 1992).

Although snow course and SNOTEL data were not intended as climate indicators, the data have been available for decades allowing researchers to incorporate SWE measurements into climate research. In particular, climatologists and hydrologists have used April 1 SWE as an annual measure of maximum snow accumulation and snow's total contribution to the water budget of a watershed. However, of concern is that April 1 SWE cannot express the effects of midwinter melt events, which are now common in the maritime snowpacks of Washington, Oregon, and California (Mote, 2003; Sproles et al. , 2013, 2017; Knowles, 2015; Cooper et al. , 2016; Mote et al. , 2018). At lower elevation sites, maximum snow accumulation often occurs prior to April 1, thereby introducing a bias to watershed budget calculations (Montoyaet al. , 2014).

The spatial representativeness of SNOTEL and snow course sites is also a concern when used for purposes outside of streamflow forecasting. For logistical reasons, snow course and SNOTEL sites occupy a relatively limited elevation range; thus, high elevation snow and rain-snow transition zones are under-sampled (Molotch and Bales, 2006; Nolin, 2012; Gleason et al. , 2017). Even with over 800 measurement sites across the western United States (NRCS https://www.wcc.nrcs.usda.gov/about/mon_automate.html), the monitoring network is sparse, with many watersheds having only one or no sites.

Moreover, as the climate continues to warm, these sites, most of which were installed in the early 1980s, may become unrepresentative of watershed-scale SWE. This is because the snowline in the mountains increases during years of warm snow drought and dry snow drought (Cooperet al. , 2016; Sproles et al. , 2017). As such, they may underestimate trends in snow cover and changes in interannual variability across the seasonal snow zone. Seasonal drought outlooks that use April $1 \mathrm{SWE}$ as a key indicator may miss key precipitation processes leading up to that date. For instance, anomalously low winter precipitation called a 'dry snow drought' (Harpold et al. , 2017) is due to the natural variability of synoptic-scale atmospheric circulation and has regional impacts across all elevations. This is important in continental mountain regions where a shift in the storm track can lead to early and mid-winter dry conditions and low SWE.

In contrast, warmer than average winter temperatures that lead to a shift from snowfall to rainfall is termed a 'warm snow drought' (Harpoldet al. , 2017) and may be caused by overall increases in winter storm temperatures. Warm snow droughts are most pronounced at low elevations and in maritime snow regions such as the Oregon and Washington Cascades and the California Sierra Nevada, where storm temperatures are close to the melting point. These examples demonstrate that different mechanisms drive warm and dry snow droughts, but there is no way to know this from April 1 SWE alone.

\subsubsection{Snow Disappearance Date}

A second previously developed snow metric is the Snow Disappearance Date (SDD). The presence or absence of snow affects landscape albedo, which in turn controls the energy balance. In snowy climates, SDD signifies the onset of spring and the start of the growing season. The elevational progression of snow disappearance in spring affects Arctic wildlife, with late spring, low elevation snow having a negative impact on populations of caribou and Dall sheep (Mahoney et al., 2018; Boelman et al. ,2019). In the western United States, SDD is associated with wildfire activity (Westerling et al. , 2006a) in the sense that SDD reflects the end of snowmelt and the onset of seasonal declines in soil moisture and fine fuel moisture content. Lundquist et al. (2013) used SDD in their comparison of forested and open sites where they showed that, in locations with relatively warmer winters, forests lose their snow cover earlier than in open areas. 
Snow disappearance date has been measured using ground-based and remotely-sensed measurements. In their study on spring snow disappearance, Foster et al. (1992) used satellite remote sensing and stationbased data to map snow cover and snow disappearance for locations in Alaska, Canada, Scandinavia, and Siberia. In the studies using station data, the manner in which SDD was determined is not always clear. In his Arctic tundra studies, Foster (1992) defined SDD as the first day of the calendar year when station-based snow depth measurements dropped below 1" (2.5cm). In their 2013 meta-analysis, Lundquist et al. (2013) listed SDD as the first day of the calendar year with no snow as reported from station data (though they didn't provide a measurement threshold). Lundquist and Lott (2010) used near-surface soil temperature measurements to detect the presence and absence of snow cover, which can be used to identify the SDD.

Such varied uses and ways of recording SDD indicate both the importance of this snow metric and a need for a spatially consistent approach to its measurement. Station-based data are inherently limited in their spatial representation of SDD, though they are critical for calibration and validation of remote sensing measurements of SDD. Temporal factors affecting SDD are also essential to consider. Transient snowfall events can influence SDD detection and can be important for hydrology and wildlife. The variable nature of spring meteorology means that it is not uncommon for spring melt to be followed by spring snowstorms that can drive the actual snow disappearance date to be days or even weeks later.

\subsubsection{Snow cover Absence and Snow cover Persistence}

Several researchers have used remotely sensed snow cover to create metrics such as snow cover absence, SA (Wayand et al. , 2018), snow persistence, SP, and snow season, SS (Hammond et al., 2018). Wayand et al. (2018) developed SA using high-resolution remote sensing data from Landsat-8 and Sentinel-2 to map snowfree areas during winter as a way to detect snow removal by wind erosion and avalanches in mountainous areas. The authors also created a snow cover persistence index that mapped snow-covered areas during summer as a way to identify wind- and avalanche deposited snow. Hammond et al. (2018) developed a remote sensing-based snow cover persistence metric though their definition of SP is "the fraction of time that snow is present on the ground." The advantage of SP, SS, and SA is that they can be computed using remote sensing data and produced at 10-30 m spatial scales, thus capturing high-resolution snow processes such as the effects of redistribution and boundaries between intermittent and seasonal snow zones (Moore et al. , 2015). However, to date, these metrics have not been produced daily or globally. There is a trade-off between temporal and spatial resolution satellite data. Finer spatial scale data such from Landsat 8 have a 16-day revisit time so even with two satellites there are long gaps in coverage. Such gaps can miss important events such as snowfall and snowmelt events.

\subsection{4 | Climatologically-based Snow Metrics}

At-risk Snow

First defined by Nolin and Daly (2006), "At-risk" snow (ARS) is when snowfall is at risk of turning to rainfall under climate warming conditions. Nolin and Daly used the PRISM 4-km gridded climate data (Daly et al. , 1993) and a decision tree approach to classify grid cells as either at-risk or not at-risk, based on monthly mean air temperature for the months of December, January, and February. The study's geographic scope covered only the Pacific Northwest (Washington, Oregon, Idaho, and western Montana), where snowfall is often close to the melting point. Their approach used the $0^{\circ} \mathrm{C}$ monthly mean temperature threshold to partition between rain and snow. The monthly mean $0^{\circ} \mathrm{C}$ threshold was selected because, though spatial and temporal differences exist, both thermodynamically and practically, it represents a shift from snowfall and snow accumulation to rainfall and declining snowpacks. Their methodology assumed that locations that might warm to that $0^{\circ} \mathrm{C}$ monthly mean temperature threshold would be at-risk of converting from snowfall to rainfall. For instance, a grid cell with a climatological mean monthly temperature of $-2^{\circ} \mathrm{C}$ for any one of the core winter months (Dec-Feb) was classified as ARS for a $+2^{\circ} \mathrm{C}$ warming scenario. This data-driven approach was simple but did not consider possible changes in atmospheric circulation and storm patterns. Moreover, the 4 -km grid-scale was too coarse to address changes at more local scales, especially in mountain 
regions where a 4-km grid cell can span a wide range of elevations and temperatures.

Frequency of a Warm Winter

Nolin and Daly (2006) also developed the Frequency of a Warm Winter (FWW) metric and as with ARS, Nolin and Daly used the PRISM gridded climate data product and monthly mean temperatures for December, January, and February. FWW is computed as the number of winters out of 30 consecutive winters that meet the "warm winter" criterion. A warm winter is defined as one in which the mean monthly temperature exceeds $0^{\circ} \mathrm{C}$ during any one of the three core winter months (December-February). Thus if three winters out of 30 winters are classified as warm in a given grid cell, the frequency is 0.1 or $10 \%$. To demonstrate possible impacts of changes in FWW, Nolin and Daly (2006) tabulated the historical and future FWW values for selected ski areas in the study region. All ski areas in the region showed increases in FWW for incremental temperature increases, but the $4-\mathrm{km}$ spatial resolution introduced uncertainty due to the range of elevations in a grid cell.

\section{DESCRIPTIONS, DATA, AND EXAMPLES OF THE NEW SNOW METRICS}

The new snow metrics described below are meant to improve upon and augment established snow metrics. The snow metrics described in the following section are intended to add value through extended spatial coverage, improved spatial resolution, more nuanced interpretation, improved data access, and user-driven flexibility.

\subsection{Snow Cover Frequency (SCF; Global)}

Snow Cover Frequency (SCF) is a global, satellite-derived, gridded product representing the observed frequency of snow cover in a grid cell. It is computed as the number of days that snow is observed on the land surface divided by the number of valid observations for a specified period (Eq. 1). We use the global, 500-m, daily, gridded snow cover product, version 6 from NASA's Moderate Resolution SpectroRadiometer (MODIS/Terra MOD10A1). Because the MOD10A1 product is daily and global, it allows the user to compute SCF anywhere globally for the MODIS period of record (February 2000-present). It is statistically valid for any period of 30 days or longer. In related work, Crumley et al. (2020) have created a version of this SCF metric for the Northern Hemisphere Water Year (WY, October 1-September 30) for WY 2001-2019. Their SCF snow metric is available as a web-based product (SnowCloudMetrics.app) developed using the Google Earth Engine (GEE) framework. In its current form, the app approach has somewhat limited flexibility for user-defined temporal and spatial subsetting. Even greater flexibility is gained if a user is willing to run the SCF code within GEE (i.e., as a GEE developer). In this case, users can select and compute SCF for any sub-annual set of sequential days within the MOD10A1 record. Users can also spatially subset SCF by user-defined polygon, US state boundary or Canadian province, elevation range, or USGS watershed. For instance, a user can draw a polygon around the California Sierra Nevada range and compute a regional SCF. The code used to produce the SCF metric, as described here, is available to users who wish to compute this product on their own using GEE.

Here, we present both a global and a regional example of SCF using MODIS data. Figure 1a shows global SCF for WY 2015. Over the western US, one can see significant differences in SCF between the two years; 2015 was a record low snow year for the western United States, and 2017 snowpack was anomalously high over the region. Figures $1 \mathrm{~b}$ and 1c take a closer look, focusing on SCF over the California Sierra Nevada for WY 2015 and WY 2017.

In another GEE application of the SCF metric, Sproles et al. (2018) found that SCF was valuable for monthly streamflow forecasting. They used SCF in their web-based, cloud-computing tool SnowCloudHydro, which combines basin-scale SCF with a simple hydrologic model for use in snow-dominated and data-sparse watersheds. Crumley et al. (2020) noted a strong association between measured SNOTEL-derived SCF and MODIS-derived SCF (using SnowCloudMetrics). We are not claiming that SCF is analogous to SWE though this may be the case in much of the western US, especially for elevations where snowpacks are very temperature sensitive. Indeed, in cold regions such as the Arctic boreal region, any relationship between SCF 
and SWE might be weak because the cold, thin snow cover can persist for many months but have a low SWE. However, we note that the SCF metric is valuable in these regions because it can detect interannual variability in the snow line elevation in the spring months (Verbyla et al. , 2017). This is important for wildlife such as Dall sheep who produce lambs at that time and for whom late-season snow cover reduces forage access, and for caribou who migrate long distances (Verbyla et al. , 2017; Mahoney et al. , 2018; Van De Kerket al. , 2018; Boelman et al. , 2019).

\subsection{Snow Disappearance Date (SDD, Northern Hemisphere extent)}

The Snow Disappearance Date is a global, satellite-derived, gridded product that maps the last day of the WY when snow is last detected in a pixel. As with SCF, SDD also uses the global, 500-m, daily, gridded snow cover product from MODIS. Starting on the last day of each WY, the algorithm searches back in the WY for the longest period without snow after a minimum of 5 days of snow cover (accounting for cloudy days). Crumley et al. (2020) computed SDD for WY 2001-2019. Like SCF, SDD has been used in wildlife studies for locations where spring snow disappearance affects the survival of young (Van De Kerk et al. , 2018). To date, SDD has not been as widely used as SCF. Still, we anticipate its value for areas where snow disappearance date has been related to the onset of the wildfire season (Westerling et al. , 2006b) and where spring vegetation phenology varies with snow cover (Huang et al. , 2018; Xie et al. , 2020).

With our revised metric, a user can compute SDD globally in about 20 seconds or use the polygon drawing tool to select a region such as the California Sierra Nevada. Figure 2a shows global SDD for WY2015 and SDD subset by polygon for the Sierra Nevada (Figures $2 \mathrm{~b}$ and 2c), providing the ability to compare a low snow year (WY 2015) with a high snow year (WY2017).

At this time, SDD spatial coverage is for the Northern Hemisphere only. In addition to SDD through the SnowCloudMetrics.app, users can also download the SDD code and run it independently using Google Earth Engine. SDD is still computed only for the Northern Hemisphere WY, but users have greater spatial subsetting options, similar to those for SCF, as described above.

[Insert Figure 2]

\subsection{Snowstorm Temperature (ST, western US extent)}

Snowstorm temperature is the mean daily temperature on days when snow accumulation occurred (Hu and Nolin, 2019, 2020). This is our only snow metric that is derived from SNOTEL station data. A storm day is determined based on measured changes in SWE. Spatial coverage is for the western United States, excluding Alaska. The snowstorm temperature data set is composed of 33 years of daily meteorological data (1984-2016) from 567 SNOTEL sites and a homogenized daily temperature dataset (TopoWx). The SNOTEL data were used to determine dates on which a snowstorm occurred and whether the snow water equivalent increased, decreased, or stayed the same. Storm day is defined as one with a measurable positive change in precipitation. SWE-gaining and SWE-losing days were recorded. TopoWx temperature data (Oyler et al. , 2015) were used to produce the dry-day and storm-day data for each of the 573 SNOTEL sites. Disaggregating winter storm days from non-storm (dry) days turns out to have a major impact on the interpretation of temperature trends. For instance, Hu and Nolin (2020) found that storm days are warming at roughly twice the rate of dry days. They also found that there were significantly fewer storm days in November. Such a trend indicates not only a delay in the start of the wet season but with declining spring snowpacks (Mote et al. , 2005, 2018), means a lengthening of the preceding dry season.

\section{4 "At-Risk" Snow (ARS, conterminous US extent)}

At-Risk Snow is computed in a manner similar to that in Nolin and Daly (2006) except that we use climate model output in this updated version of the ARS metric. ARS is computed using the gridded NASA Earth 
Exchange Downscaled Climate Projections (NEX-DCP30) 30 arcsec (approximately 800-m) dataset (Thrasher et al. , 2013), which covers the conterminous United States. We compute mean temperature from their average monthly maximum and minimum temperature data from 33 downscaled climate models and four Representative Concentration Pathways (RCPs) (Meinshausen et al. , 2011). The data set includes retrospective model runs covering the historical period from 1950 to 2005, and prospective model runs for 2006 to 2099. The spatial domain is the conterminous United States (Figure 3). The ARS gridded map product depicts model grid cells where December-February monthly mean temperatures will reach the $0^{\circ} \mathrm{C}$ threshold.

We have produced a fully functional code running on GEE that allows the user to compute At-Risk Snow for any range of years in the period covered by the NASA NEX-DCP30 downscaled climate data. Users can spatially and temporally subset, visualize, explore, and download the FWW data of interest. A user can filter by emissions scenario, global climate model, spatial extent, and period. A user can select from any of four CMIP5 emissions scenarios (RCP2.6, RCP4.5, RCP6.0, and RCP8.5) and from numerous downscaled (800-m) model output (23 models for RCP2.6; 33 models for RCP4.5; 17 models for RCP6.0; and 31 models for RCP8.5). If desired, a user can subset by watershed using the USGS hydrologic unit codes (HUC levels $2-12)$.

[Insert Figure 3]

\subsection{Frequency of a Warm Winter (FWW, conterminous US extent)}

As with the At-Risk Snow metric, FWW uses the monthly maximum and minimum temperature data from NEX-DCP30, computing mean temperature from their average. The definition of FWW is the same as in Nolin and Daly (2006), but the geographic scope extends to cover the conterminous US at 800-m spatial resolution. The temporal range is 1950-2005 for historic FWW and 2006-2099 for future FWW.

For users to compute FWW, we have produced code that runs on GEE. This allows the user to calculate FWW for any range of years in the period covered by the NASA NEX-DCP30 downscaled climate data. As with ARS, users can spatially and temporally subset, visualize, explore, and download the FWW data of interest. A user can filter by emissions scenario, global climate model, spatial extent, and range of years. If desired, users can subset by watershed using the USGS hydrologic unit codes (HUC levels 2-12). When computing FWW, we recommend that users specify a range of at least 30 years so that the calculated values are the empirical equivalent of a statistical probability. For instance, a user can compare FWW for 1979-2009 (historical) with FWW for 2035-2069 (mid-century) or 2079-2099 (late-century). The 800-m gridded data are sufficiently fine spatial resolution that users can explore projected FWW changes for spatial extent as large as the conterminous United States and as small as a headwater catchment, an urban area, and even along an elevation gradient in a ski area.

Figure 4 shows an example of FWW for the conterminous United States and selected ski areas, for three time periods: historic (1970-1999) and RCP8.5 mid-century (2035-2064), and RCP8.5 late-century (2070-2099).

In a recent application of FWW, Nolin assisted the city of Whitefish, Montana with their Climate Action Plan (City of Whitefish, 2018). The winter economy of Whitefish depends on the success of the nearby ski area, Whitefish Mountain Resort. For this report, Non subset and computed FWW for the lower, mid- and summit elevations of the ski area for different climate scenarios and for mid-century and late-century. This is a straightforward example of the use of the FWW metric for non-scientists seeking climate change information at the local-to-regional scale. Table 1 gives FWW values for the selected ski areas shown in Figure 4. These represent major ski resorts in a maritime snow climate (Squaw Valley, CA; Mt. Bachelor, OR), northern Rocky Mountains (Big Sky, MT), central Rocky Mountains (Vail, CO), and northern Appalachian Mountains (Killington, VT).

[Insert Figure 4]

[Insert Table 1] 


\section{CONCLUSIONS}

We have introduced several new snow metrics that can be used alone or in conjunction with existing snow metrics. These new snow metrics are intended to provide a greater understanding of snow's spatial and temporal variability and be relevant to a wide range of researchers and stakeholders. We have produced three retrospective snow metrics: snow cover frequency (SCF), snow disappearance date (SDD), and storm temperature (ST). Our SCF and SDD metrics are spatially extensive and readily available to augment station data or to provide snow information where none currently exists. In future work, we will expand the SDD metric to the Southern Hemisphere. The ST data from SNOTEL sites provide critical information on snowstorms' changing characteristics across the western United States. It would be valuable to extend the ST timeseries to better understand trends and to capture some of the recent interannual variability in storms. The SCF and SDD data that are available through SnowCloudMetrics.app (Crumley et al. , 2020) will be annually updated. Still, users who want greater flexibility and near-real-time results can download code to be run through Google Earth Engine. These remote sensing-derived metrics, current produced using the MODIS binary snow cover algorithm have the potential for improvement by instead using fractional snow covered area (Painter et al., 2009; Rittger et al., 2013) or using data from Landsat 8, Sentinel 2 or similar finer resolution sensors.

In addition to the retrospective metrics, we have produced two prospective snow metrics: At-Risk Snow (ARS) and Frequency of a Warm Winter (FWW). The downscaled climate model output used to create ARS and FWW are best they have ever been, and a logical next step is for these two metrics to be expanded globally. As models and downscaling methods continue to improve, these metrics should be updated and produced on a global extent. Previous snow metrics have focused almost exclusively on western US water resources. While this region is important, there is a nationwide need for snow information with broader relevance.

The snow metrics presented here are simple enough to "tell the story" of snowpack changes over space, are spatially extensive (in some cases, global), and are produced in a consistent manner using high-quality data and are not overly complicated in their interpretation. We anticipate and hope that these new snow metrics will serve multiple sectors and stakeholder groups, some of whom have never used such information in the past.

\section{ACKNOWLEDGEMENTS}

This research was supported by the National Aeronautics and Space Administration under grant \#NNX16AG35G. No conflicts of interest, real or perceived, financial or by affiliation, exist for any author.

\section{Code and Data Availability}

The data that support the findings of this study are openly available in the following repositories and websites:

SnowCloudMetrics.app is available online www.snowcloudmetrics.app (last accessed 28 October 2020).

GitHub page for SnowCloudMetrics information and scripts is available online at https://github. com/orgs/SnowCloudMetrics (last accessed 28 October 2020).

GitHub page for At-Risk snow and Frequency of a Warm Winter Google Earth Engine scripts is available online at https://github.com/AnneNolin/NewSnowMetrics (last accessed 28 October 2020).

Google Earth Engine datasets are available online at https://developers.google.com/earth-engine/ datasets/catalog (last accessed 28 October 2020).

\section{REFERENCES}


Boelman NT, Liston GE, Gurarie E, Meddens AJH, Mahoney PJ, Kirchner PB, Bohrer G, Brinkman TJ, Cosgrove CL, Eitel JUH, et al. 2019. Integrating snow science and wildlife ecology in Arctic-boreal North America.Environmental Research Letters 14 (1) DOI: 10.1088/1748-9326/aaeec1

City of Whitefish. 2018. City of Whitefish Climate Action Plan Available at: https://www.cityofwhitefish.org/229/Climate-Action-Plan

Cooper MG, Nolin AW, Safeeq M. 2016. Testing the recent snow drought as an analog for climate warming sensitivity of Cascades snowpacks.Environmental Research Letters 11 (8) DOI: 10.1088/17489326/11/8/084009

Crumley R, Nolin A, Mar E, Sproles E. 2020. SnowCloudMetrics - Snow information for everyone. Remote Sensing : $1-18$

Daly C, Neilsen RP, Phillips DL. 1993. Daly et al. Journal of Applied Meteorology 33 : 140-158

Foster JL, Winchester JW, Dutton EG. 1992. The date of snow disappearance on the Arctic tundra as determined from satellite, meteorological station and radiometric in situ observations. IEEE Transactions on Geoscience and Remote Sensing 30 (4): 793-798 DOI: 10.1109/36.158874

Garen D. 1992. Garen_JWRPM_1992.pdf. Journal of Water Resources Planning and Management 118 (6): $654-670$

Gleason KE, Nolin AW, Roth TR. 2017. Developing a representative snow-monitoring network in a forested mountain watershed.Hydrology and Earth System Sciences 21 (2): 1137-1147 DOI: 10.5194/hess-21-11372017

Hagenstad M, Burakowski E, Hill R. 2018. The Economic Contributions of Winter Sports in a Changing Climate. Protect Our Winter POW(February): 1-69

Hammond JC, Saavedra FA, Kampf SK. 2018. Global snow zone maps and trends in snow persistence 2001-2016. International Journal of Climatology 38 (12): 4369-4383 DOI: 10.1002/joc.5674

Harpold AA, Dettinger M, Rajagopal S. 2017. Defining snow drought and why it matters. Eos 98 (5): 15-17 DOI: $10.1029 / 2017$ eo068775

Hu JM, Nolin AW. 2019. Snowpack Contributions and Temperature Characterization of Landfalling Atmospheric Rivers in the Western Cordillera of the United States. Geophysical Research Letters46 (12) DOI: 10.1029/2019GL083564

Hu JM, Nolin AW. 2020. Widespread warming trends in storm temperatures and snowpack fate across the Western United States. Environmental Research Letters 15 (3) DOI: 10.1088/1748-9326/ab763f

Huang K, Zu J, Zhang Y, Cong N, Liu Y, Chen N. 2018. Impacts of snow cover duration on vegetation spring phenology over the Tibetan Plateau. Journal of Plant Ecology 12 (3): 583-592 DOI: 10.1093/jpe/rty051

IPCC, Portner HO, Roberts DC, Masson-Delmotte V, Zhai P, Tignor M, Poloczanska E, Mintebeck K, Nicolai M, Okem A, et al. 2019. IPCC The Ocean and Cryosphere in a Changing Climate Summary for Policmakers.IPCC Special Report on the Ocean and Cryosphere in a Changing Climate (September): SPM1-SPM-42 Available at: https://report.ipcc.ch/srocc/pdf/SROCC_SPM_Approved.pdf

Jennings KS, Winchell TS, Livneh B, Molotch NP. 2018. Spatial variation of the rain-snow temperature threshold across the Northern Hemisphere.Nature Communications 9 DOI: 10.1038/s41467-018-03629-7

Van De Kerk M, Verbyla D, Nolin AW, Sivy KJ, Prugh LR. 2018. Range-wide variation in the effect of spring snow phenology on Dall sheep population dynamics. Environmental Research Letters 13(7) DOI: 10.1088/1748-9326/aace64

Knowles N. 2015. Trends in snow cover and related quantities at weather stations in the conterminous United States. Journal of ClimateDOI: 10.1175/JCLI-D-15-0051.1 
Lundquist JD, Lott F. 2010. Using inexpensive temperature sensors to monitor the duration and heterogeneity of snow-covered areas. Water Resources Research 46 (4): 8-13 DOI: 10.1029/2008WR007035

Lundquist JD, Dickerson-Lange SE, Lutz JA, Cristea NC. 2013. Lower forest density enhances snow retention in regions with warmer winters: A global framework developed from plot-scale observations and modeling. Water Resources Research DOI: 10.1002/wrcr.20504

Mahoney PJ, Liston GE, LaPoint S, Gurarie E, Mangipane B, Wells AG, Brinkman TJ, Eitel JUH, Hebblewhite M, Nolin AW, et al. 2018. Navigating snowscapes: scale-dependent responses of mountain sheep to snowpack properties. Ecological Applications 28 (7): 1715-1729 DOI: 10.1002/eap.1773

Meinshausen M, Smith SJ, Calvin K, Daniel JS, Kainuma MLT, Lamarque J, Matsumoto K, Montzka SA, Raper SCB, Riahi K, et al. 2011. The RCP greenhouse gas concentrations and their extensions from 1765 to 2300.Climatic Change 109 (1): 213-241 DOI: 10.1007/s10584-011-0156-z

Milly PCD, Betancourt J, Falkenmark M, Hirsch RM, Kundzewicz ZW, Lettenmaier DP, Stouffer RJ. 2008. Climate change: Stationarity is dead: Whither water management? Science 319 (5863): 573-574 DOI: 10.1126/science.1151915

Molotch NP, Bales RC. 2006. Comparison of ground-based and airborne snow surface albedo parameterizations in an alpine watershed: Impact on snowpack mass balance: COMPARISON OF SNOW ALBEDO PARAMETERIZATIONS. Water Resources Research 42 (5): 1-12 DOI: 10.1029/2005WR004522

Montoya EL, Dozier J, Meiring W, Church JE, Hammond JC, Saavedra FA, Kampf SK. 2014. How Does Snow Persistence Relate to Annual Streamflow in Mountain Watersheds of the Western U.S. With Wet Maritime and Dry Continental Climates? Water Resources Research 54 (4): 529 DOI: 10.2307/209242

Moore C, Kampf S, Stone B, Richer E. 2015. A GIS-based method for defining snow zones: application to the western United States. Geocarto International 30 (1): 62-81 DOI: 10.1080/10106049.2014.885089

Mote PW. 2003. Trends in snow water equivalent in the Pacific Northwest and their climatic causes. Geophysical Research Letters30 (12) DOI: 10.1029/2003GL017258

Mote PW, Hamlet AF, Clark MP, Lettenmaier DP. 2005. Declining mountain snowpack in western north America. Bulletin of the American Meteorological Society 86 (1): 39-49 DOI: 10.1175/BAMS-86-1-39

Mote PW, Li S, Lettenmaier DP, Xiao M, Engel R. 2018. Dramatic declines in snowpack in the western US. Nature Climate and Atmospheric Science 1 (2): 1-6 DOI: 10.1038/s41612-018-0012-1

Nolin AW. 2012. Perspectives on climate change, mountain hydrology, and water resources in the Oregon Cascades, USA. Mountain Research and Development 32 (SUPPL. 1) DOI: 10.1659/MRD-JOURNAL-D11-00038.S1

Nolin AW, Daly C. 2006. Mapping 'at risk' snow in the Pacific Northwest.Journal of Hydrometeorology 7 (5) DOI: $10.1175 / J H M 543.1$

Oyler JW, Ballantyne A, Jencso K, Sweet M, Running SW. 2015. Creating a topoclimatic daily air temperature dataset for the conterminous United States using homogenized station data and remotely sensed land skin temperature. International Journal of Climatology 35(9): 2258-2279 DOI: 10.1002/joc.4127

Painter TH, Rittger K, McKenzie C, Slaughter P, Davis RE, Dozier J. 2009. Retrieval of subpixel snow covered area, grain size, and albedo from MODIS. Remote Sensing of Environment 113 (4): 868-879 DOI: 10.1016/j.rse.2009.01.001

Rittger K, Painter TH, Dozier J. 2013. Assessment of methods for mapping snow cover from MODIS. Advances in Water Resources 51 : 367-380 DOI: 10.1016/j.advwatres.2012.03.002

Serreze MC, Clark MP, Armstrong RL, McGinnis DA, Pulwarty RS. 1999. Characteristics of the western 
United States snowpack from snowpack telemetry (SNOTEL) data. Water Resources Research 35(7): 21452160 DOI: 10.1029/1999WR900090

Sproles EA, Crumley RL, Nolin AW, Mar E, Moreno JIL. 2018. SnowCloudHydro-A new framework for forecasting streamflow in snowy, data-scarce regions. Remote Sensing 10 (8) DOI: 10.3390/rs10081276

Sproles EA, Nolin AW, Rittger K, Painter TH. 2013. Climate change impacts on maritime mountain snowpack in the Oregon Cascades. Hydrology and Earth System Sciences 17 (7) DOI: 10.5194/hess-17-2581-2013

Sproles EA, Roth TR, Nolin AW. 2017. Future snow? A spatial-probabilistic assessment of the extraordinarily low snowpacks of 2014 and 2015 in the Oregon Cascades. Cryosphere 11 (1) DOI: 10.5194/tc-11-331-2017

Thrasher B, Xiong J, Wong W, Melton F, Michaelis A, Nemani R. 2013. Downscaled climate projections suitable for resource management.Eos, Transactions American Geophysical Union 94 (37): 321-323

Topographically driven differences in energy and water constrain climatic control on forest carbon sequestration. 2017. Ecosphere8 (4): e01797 DOI: 10.1002/ecs2.1797

Verbyla D, Hegel T, Nolin AW, van de Kerk M, Kurkowski TA, Prugh LR. 2017. Remote sensing of 20002016 alpine spring snowline elevation in dall sheep mountain ranges of Alaska and Western Canada. Remote Sensing 9 (11) DOI: 10.3390/rs9111157

Wayand NE, Marsh CB, Shea JM, Pomeroy JW. 2018. Globally scalable alpine snow metrics. Remote Sensing of Environment 213 (April): 61-72 DOI: 10.1016/j.rse.2018.05.012

Westerling AL, Hidalgo HG, Cayan DR, Swetnam TW. 2006a. Warming and Earlier Spring Increase Western U.S. Forest Wildfire Activity.Science 313 (5789): 940-943 DOI: 10.1126/science.1128834

Westerling AL, Hidalgo HG, Cayan DR, Swetnam TW. 2006b. Warming and earlier spring increase Western U.S. forest wildfire activity.Science 313 (5789): 940-943 DOI: 10.1126/science.1128834

Xie J, Jonas T, Rixen C, de Jong R, Garonna I, Notarnicola C, Asam S, Schaepman ME, Kneubühler M. 2020. Land surface phenology and greenness in Alpine grasslands driven by seasonal snow and meteorological factors.Science of the Total Environment 725 : 138380 DOI: 10.1016/j.scitotenv.2020.138380

\section{TABLES}

Table 1. Frequency of a Warm Winter for selected ski areas shown in Figure 4. FWW values were computed using RCP8.5 and expressed as a percent for each 30-year period.

\begin{tabular}{|c|c|c|c|c|c|}
\hline Location & Location & Elevation $(\mathrm{m})$ & $\begin{array}{l}\text { Historical } \\
1970-1999\end{array}$ & $\begin{array}{l}\text { Mid-century } \\
\text { 2035-2064 }\end{array}$ & $\begin{array}{l}\text { Late-century } \\
2070-2099\end{array}$ \\
\hline \multirow{3}{*}{$\begin{array}{l}\text { Squaw Valley, } \\
\text { CA }\end{array}$} & base & & 53.3 & 96.67 & 100 \\
\hline & mid-mtn & & 16.67 & 86.67 & 100 \\
\hline & summit & & 13.3 & 70 & 96.67 \\
\hline \multirow{3}{*}{$\begin{array}{l}\text { Mt. Bachelor, } \\
\text { OR }\end{array}$} & base & & 13.3 & 53.3 & 96.67 \\
\hline & mid-mtn & & 0 & 10 & 70 \\
\hline & summit & & 0 & 3.3 & 36.67 \\
\hline \multirow[t]{3}{*}{ Big Sky, MT } & base & & 0 & 23.3 & 63.3 \\
\hline & mid-mtn & & 0 & 0 & 56.67 \\
\hline & summit & & 0 & 0 & 26.67 \\
\hline \multirow[t]{3}{*}{ Vail, CO } & base & & 0 & 3.3 & 36.67 \\
\hline & mid-mtn & & 0 & 0 & 13.3 \\
\hline & summit & & 0 & 0 & 6.67 \\
\hline Killington, VT & base & & 0 & 10 & 66.67 \\
\hline
\end{tabular}




\begin{tabular}{|c|c|c|c|c|c|}
\hline Location & Location & Elevation (m) & $\begin{array}{l}\text { Historical } \\
1970-1999\end{array}$ & $\begin{array}{l}\text { Mid-century } \\
\text { 2035-2064 }\end{array}$ & $\begin{array}{l}\text { Late-century } \\
2070-2099\end{array}$ \\
\hline & mid-mtn & & 0 & 10 & 50 \\
\hline & summit & & 0 & 3.3 & 30 \\
\hline
\end{tabular}

\section{FIGURE LEGENDS}

Figure 1. Global snow cover frequency January 1-April 1, 2015 (a) and SCF for the Sierra Nevada for January 1-April 1, 2015 (b) and January 1-April 1, 2017 (c).

Figure 2. Global snow disappearance date for WY2015 (a) and SCF for the Sierra Nevada for WY2015 (b) and WY2017 (c).

Figure 3. At-risk snow mapped for the conterminous United States for the historical period (1970-1999) (a) and RCP8.5 for late-century (2070-2099) (b), and the Sierra Nevada, showing shifts in snow category from historical to late century for RCP8.5 (c).

Figure 4. FWW for the conterminous United States for three time periods: historic (1970-1999) and RCP8.5 mid-century (2035-2064), and RCP8.5 late-century (2070-2099).Selected ski areas are labeled. The right column depicts the Squaw Valley ski resort for each of the three periods.
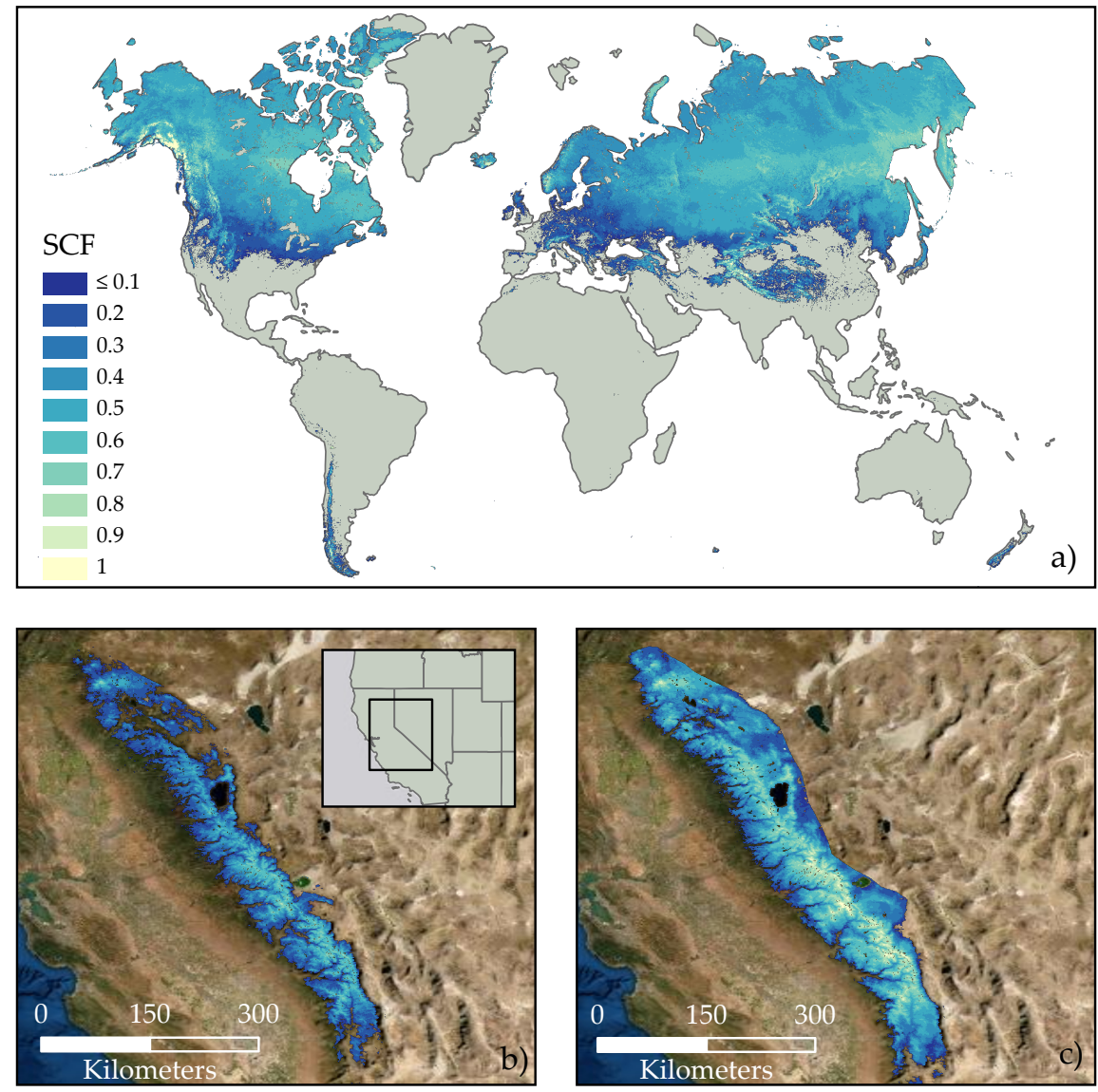

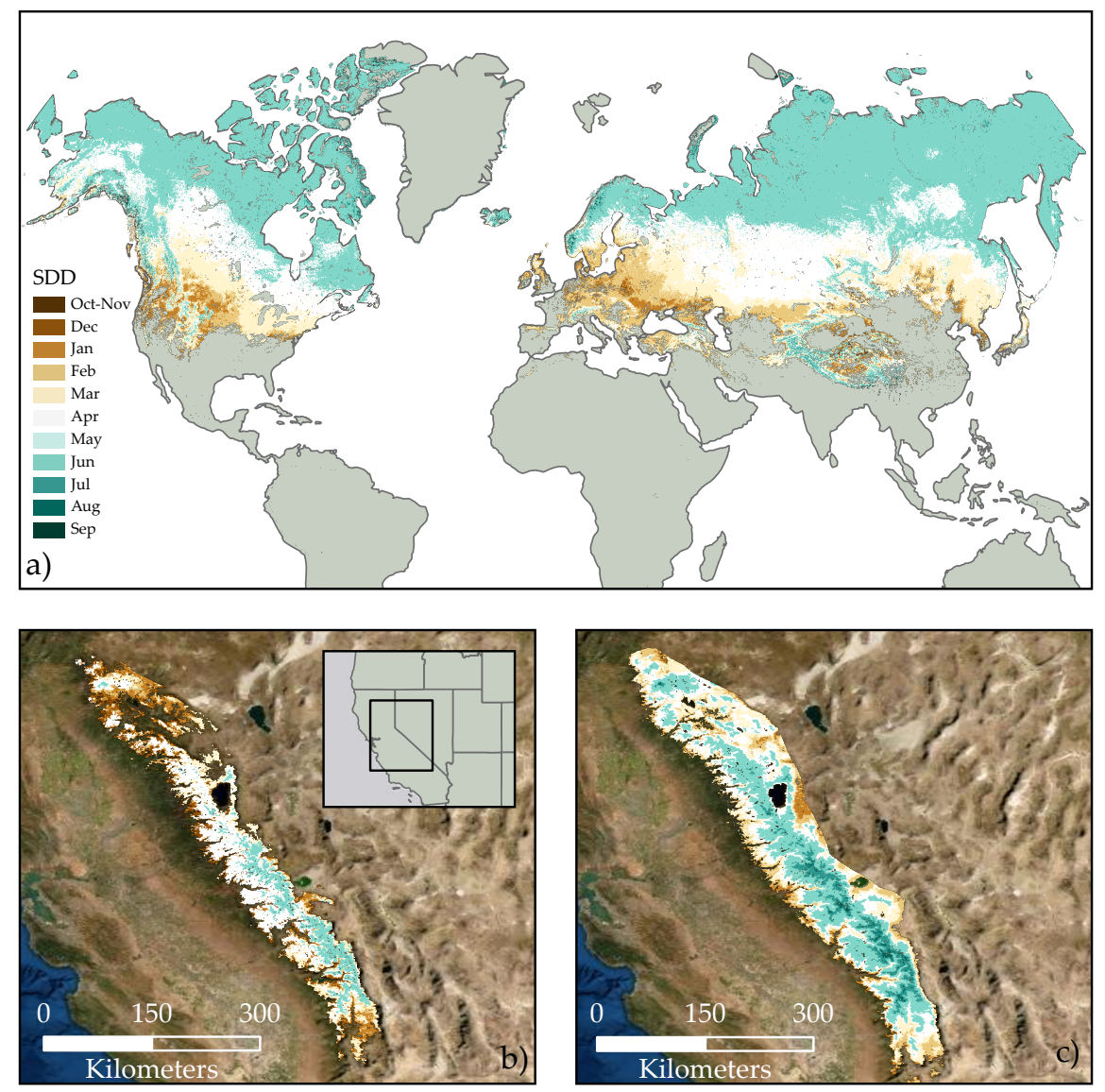

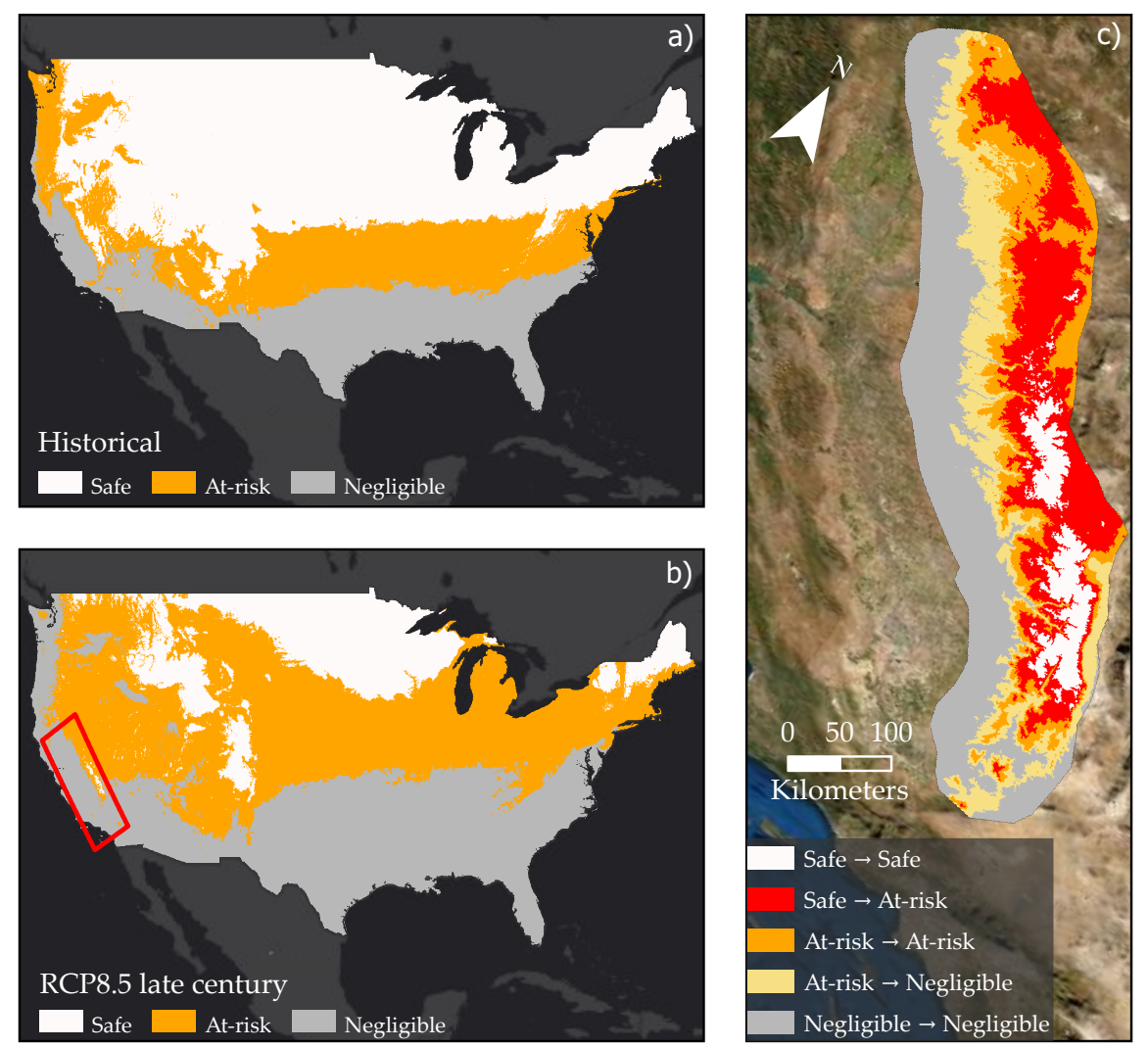

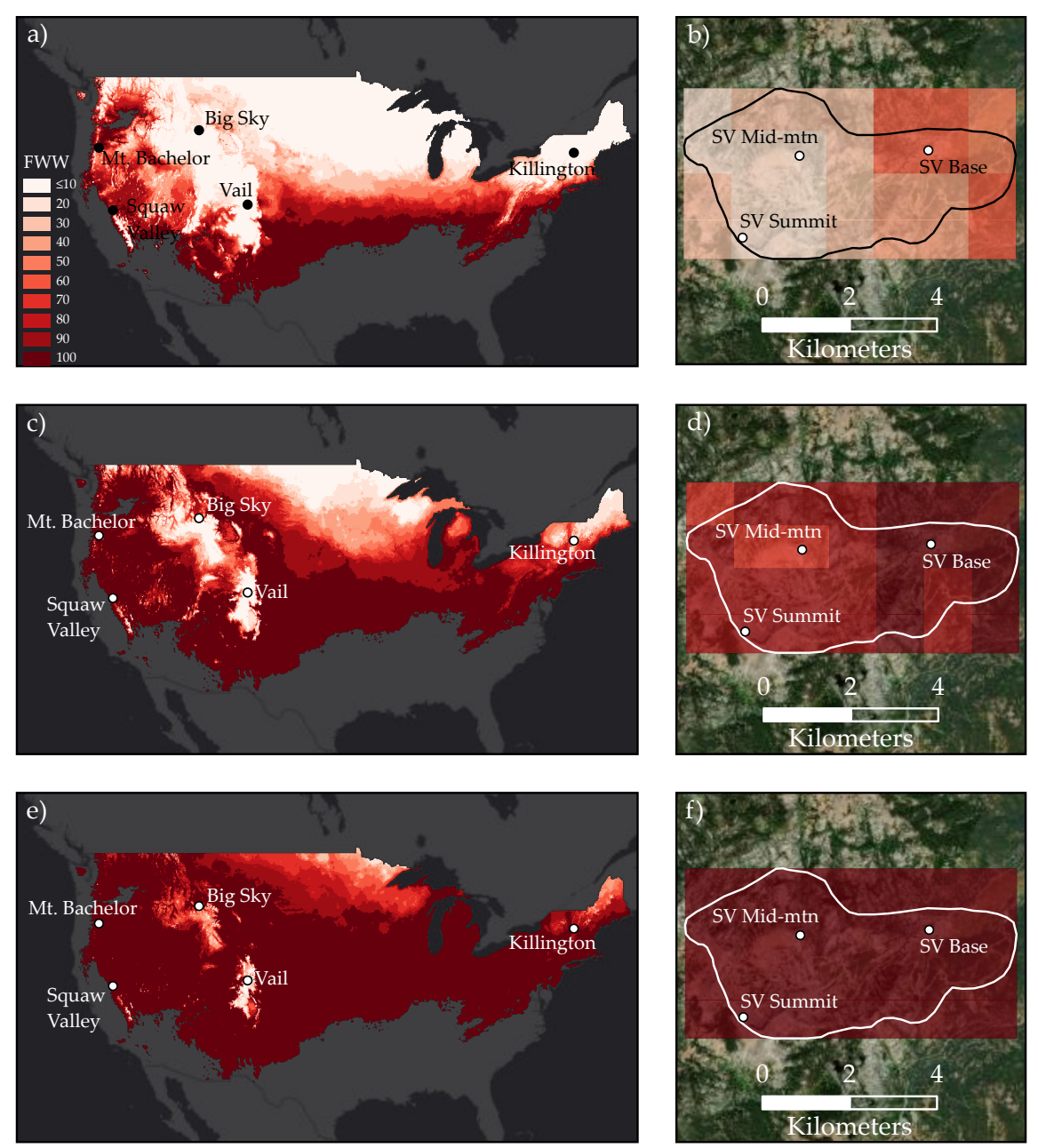

\section{Hosted file}

Table1.pdf available at https://authorea.com/users/371848/articles/490042-new-snow-metricsfor-a-warming-world 